\title{
Characterization of Extracellular Alkaline Proteases and Collagenase Induction in Vibrio alginolyticus
}

\author{
By PATRICIA HARE, ${ }^{1}$ T. SCOTT-BURDEN ${ }^{2}$ AND D. R. WOODS ${ }^{1 *}$ \\ ${ }^{1}$ C.S.I.R. Applied Microbial Genetics Unit, Department of Microbiology, University of Cape \\ Town, Rondebosch 7700, South Africa
}

${ }^{2}$ Department of Medical Biochemistry, University of Cape Town, Rondebosch 7700, South Africa

(Received 13 May 1982; revised 23 August 1982)

\begin{abstract}
The number and approximate molecular weights of extracellular alkaline proteases produced by Vibrio alginolyticus were determined by gelatin-PAGE. Three major bands of protease activity with apparent molecular weights of approximately 28000,22500 and 19500 (proteases 1, 2 and 3 , respectively) and two minor bands of protease activity with apparent molecular weights of approximately 15500 and 14500 (proteases 4 and 5, respectively) were obtained after gelatinPAGE. The activities of the five proteases were inhibited by serine protease inhibitors but their activities were not affected by inhibitors of trypsin-like enzymes. Histidine, which inhibited $V$. alginolyticus collagenase, did not inhibit the activities of the alkaline serine proteases. The production of protease 1 , however, was enhanced by histidine. Protease 1 production was also affected by temperature and production was depressed at $37^{\circ} \mathrm{C}$. Gelatin-PAGE of a commercial $V$. alginolyticus collagenase preparation revealed four bands of activity which were identified as collagenases with apparent molecular weights of approximately 45000,38500 , 33500 and 31000 . The collagenase preparation was contaminated with two serine proteases. The release of $\left[{ }^{3} \mathrm{H}\right]$ proline from collagen matrices produced by smooth muscle cells was shown to be a sensitive assay for bacterial collagenases and was used to show that $V$. alginolyticus produced a basal constitutive level of extracellular collagenase. The constitutive levels of collagenase were affected by aeration.
\end{abstract}

\section{INTRODUCTION}

Vibrio alginolyticus cultures possess extracellular alkaline serine protease activity. Preliminary studies with enzyme inhibitors suggested that proteolytic activity could be due to more than one enzyme (Long et al., 1981). Histidine and urocanic acid stimulate the production of alkaline protease activity (Long et al., 1981). We have now characterized the alkaline proteases in order to determine how many proteases are produced by $V$. alginolyticus and how they are regulated by histidine.

The $V$. alginolyticus strain we have used is also of interest because it produces an extracellular collagenase with a high specific activity (Lecroisey et al., 1975). The enzyme is synthesized as the culture enters the stationary growth phase and is induced either by peptone or by collagen and its high molecular weight fragments (Keil-Dlouha et al., 1976; Reid et al., 1978; Robbertse et al., 1978; Reid et al., 1980). Keil-Dlouha et al. (1976) suggested that the collagenase-sensitive bond and tertiary structure of collagen were required for induction. The lower inducing activity of peptone after digestion with collagenase (Reid et al., 1980) supported this suggestion. In the experiments on the induction of collagenase discussed above, the enzyme was assayed by the

Abbreviations: DFP, diisopropyl fluorophosphate; NPGB, nitrophenylguanidobenzoate; PHMB, phydroxymercuribenzoate, sodium salt : PMSF, phenylmethylsulphonyl fluoride; TLCK, tosyl-lysine chloromethyl ketone: TPCK, tosyl-phenylalanine chloromethyl ketone. 
method of Wünsch \& Heidrich (1963) which uses a synthetic chromogenic substrate. This method lacks the sensitivity of a radioactive assay and therefore we have measured the production of collagenase by using a sensitive radioactive assay procedure which involves the release of $\left[{ }^{3} \mathrm{H}\right]$ proline from a labelled collagen matrix (Jones \& Scott-Burden, 1979).

\section{METHODS}

Bacterial strain and media. We used the collagenolytic strain isolated and classified as Achromobacter iophagus by Welton \& Woods (1973) but recently reclassified as Vibrio alginolyticus (Reid et al., 1980). The bacterium was maintained on the complex medium of Welton \& Woods (1973). The Casamino acid and peptone media have been described previously (Reid et al., 1980). The medium designated as low-SNP medium (nitrogen and carbon limiting) contained $2 \mathrm{~mm}$-disodium succinate, $1 \mathrm{~mm}-\left(\mathrm{NH}_{4}\right)_{2} \mathrm{SO}_{4}, 1 \mathrm{mM}-\mathrm{KH}_{2} \mathrm{PO}_{4}$ and $0.4 \mathrm{M}-\mathrm{NaCl}$ in $0.1 \mathrm{M}$ Tris $/ \mathrm{HCl}$ buffer ( $\mathrm{pH} 7 \cdot 6)$.

Production of labelled collagen matrices. Smooth muscle cells were used to produce a $\left[{ }^{3} \mathrm{H}\right]$ proline-labelled matrix in $35 \mathrm{~mm}$ diam. culture dishes by the method of Jones \& Scott-Burden (1979). The cells cultured in the presence of $\left.\mathrm{L}-[3,4(\mathrm{n}))^{-3} \mathrm{H}\right]$ proline (Amersham) synthesized an extensive radioactively labelled matrix containing glycoprotein(s), elastin and collagen, which remained on the bottom of the culture dishes following the removal of the producer cells by mild alkaline treatment. The matrix was treated with trypsin and elastase and sequential enzyme analysis demonstrated that $34 \%$ of the $\left[{ }^{3} \mathrm{H}\right.$ ] proline was released by trypsin and a further $43 \%$ by elastase (Jones \& Scott-Burden, 1979). After treatment with trypsin and elastase the remaining radioactivity could only be released enzymically with collagenase. All the experiments were carried out with collagen matrices which had been treated with trypsin and elastase.

Growth conditions for enzyme studies. Overnight $V$. alginolyticus cultures $(10 \mathrm{ml})$ in $2.5 \%(\mathrm{w} / \mathrm{v})$ Casamino acid medium were used to inoculate $100 \mathrm{ml}$ minimal medium cultures which were aerated on an orbital shaker at 130 r.p.m. for $4 \mathrm{~h}$ at $30^{\circ} \mathrm{C}$. The cells were harvested, washed twice by centrifugation and resuspended in $20 \mathrm{ml}$ lowSNP medium. Samples $(2 \mathrm{ml})$ were added to the $\left[{ }^{3} \mathrm{H}\right]$ proline-labelled collagen dishes which were incubated at $30^{\circ} \mathrm{C}$ in an orbital shaking incubator $(130 \mathrm{r}$.p.m.). Samples $(0.1 \mathrm{ml})$ were removed at intervals, added to $5 \mathrm{ml}$ scintillation fluid and the radioactivity determined in a Packard Liquid Scintillation Spectrometer. Digestion of the collagen matrix was also carried out with solutions of a $V$. alginolyticus collagenase preparation $\left(1 \mathrm{mg} \mathrm{ml}^{-1}\right.$; Boehringer).

Enzyme assays. All enzyme assays were done at standardized cell densities. Each sample was assayed in duplicate and experiments were repeated at least three times. Collagenase was assayed either by the release of radioactivity from the collagen matrices or by the method of Wünsch \& Heidrich (1963) using the synthetic collagenase substrate phenyl-azobenzyloxycarbonyl-L-propyl-L-leucyl-glycyl-L-propyl-D-arginine (Fluka, Buchs, Switzerland) as previously described (Reid et al., 1978). Alkaline protease activity was assayed using the synthetic substrate azocasein (Sigma) (Long et al., 1981). One unit of alkaline protease activity is defined as the amount of enzyme that gives an increase in absorbance of 0.1 at $440 \mathrm{~nm}$ in $30 \mathrm{~min}$ at $40^{\circ} \mathrm{C}$.

$P A G E$. Extracellular proteases and collagenases produced by $V$. alginolyticus were characterized by PAGE in slab gels containing SDS and gelatin as a copolymerized substrate (Heussen \& Dowdle, 1980). Cultures were sedimented by centrifugation in a microfuge and $1.0 \mathrm{ml}$ supernatant samples were mixed with $0.1 \mathrm{ml} \operatorname{SDS}(25 \%$, $\mathrm{w} / \mathrm{v})$ and $0.1 \mathrm{ml}$ glycerol and incubated at $37^{\circ} \mathrm{C}$ for $30 \mathrm{~min}$. PAGE was carried out at $4{ }^{\circ} \mathrm{C}$ in SDS-gelatinpolyacrylamide gels at $\mathrm{pH} 7.6$ and 8.8 at constant currents of 20 and $8 \mathrm{~mA}$ respectively. Each lane was loaded with $1 \cdot 3 \mu \mathrm{g}$ protein.

After electrophoresis the gels were washed in Triton X-100 for $1 \mathrm{~h}$ at $4{ }^{\circ} \mathrm{C}$ to remove the SDS and restore enzyme activity. The gels were incubated in $0.1 \mathrm{M}$-glycine buffer $(\mathrm{pH} 7.6$ or 8.8$)$ for $3.5 \mathrm{~h}$ at $37^{\circ} \mathrm{C}$ and then stained for protein with $2 \%(\mathrm{w} / \mathrm{v})$ amido black. The bands of proteolytic activity were revealed as areas depleted of gelatin. Photographs of gels were scanned with a Beckman DU-8 spectrophotometer with a gel scanner attachment. The effects of the following protease inhibitors on the activities of the proteases were determined by adding the inhibitors to the gelatin gels during incubation in $0.1 \mathrm{M}$-glycine buffer: DFP (10 mM), PMSF (10 mM), EDTA (10 mM), $o$-phenanthroline (1 mM), TLCK (1 mM), TPCK (1 mM), NPGB (1 mM), benzamidine (10 mM), PHMB $1 \mathrm{mM})$, iodoacetamide $(10 \mathrm{mM})$, soybean trypsin inhibitor $(1 \mathrm{mM})$, lima bean inhibitor $(1 \mathrm{mM})$, bovine pancreatic trypsin inhibitor (trasylol) $(1 \mathrm{mM})$ and ovomucoid $(1 \mathrm{mM})$. Inhibition of protease activity by histidine $(0.5 \%, \mathrm{w} / \mathrm{v})$ and the divalent cations from $\mathrm{CaCl}_{2}, \mathrm{MgCl}_{2}, \mathrm{MgSO}_{4}, \mathrm{LiCl}, \mathrm{ZnCl}_{2}$ and $\mathrm{HgCl}_{2}$, all at I mM, was also determined.

Source of chemicals. DFP, NPGB, PHMB, TLCK, TPCK, benzamidine, soybean trypsin inhibitor and lima bean inhibitor were obtained from Sigma. PMSF was obtained from Schwarz Mann, Orangeburg, New York, U.S.A., iodoacetamide from BDH, trasylol from Bayer AG., Leverkusen, West Germany, ovomucoid from Worthington and EDTA from Merck. The molecular weight markers were obtained from Pharmacia and the collagenase preparation from Boehringer. 
(a)

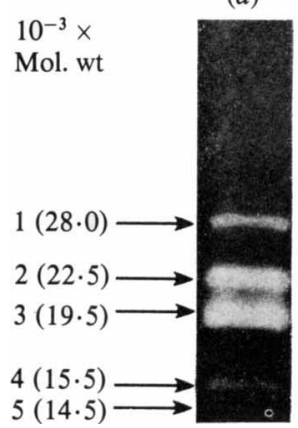

(b)

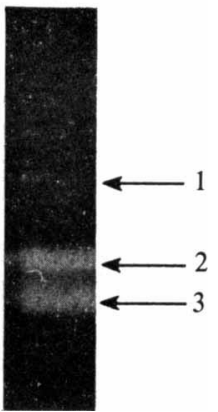

Fig. 1. Extracellular protease activity of $V$. alginolyticus cultures after gelatin-PAGE at $\mathrm{pH} 7 \cdot 6$ and $8 \cdot 8$. The lanes represent culture supernatants without inhibitors at $(a) \mathrm{pH} 7.6$ and $(b) \mathrm{pH} 8.8$. The arrows indicate the positions of proteases $1,2,3,4$ and 5 . Each lane was loaded with $1.3 \mu \mathrm{g}$ protein.

Table 1. Effect of protease inhibitors and salts on the activity at pH 7.6 and 8.8 of extracellular proteases produced by $V$. alginolyticus

After gelatin PAGE the inhibitors were added to the gelatin gels during incubation in $0.1 \mathrm{M}$-glycine buffer for $3.5 \mathrm{~h}$. The gels were then stained with amido black. + , Total inhibition of protease activity after gelatin PAGE; - no inhibition of protease activity after gelatin-PAGE.

Inhibitor

DFP, PMSF, EDTA

o-Phenanthroline

TLCK. TPCK, NPGB, benzamidine,

PHMB, iodoacetamide, soybean trypsin inhibitor, lima bean

inhibitor, trasylol, ovomucoid

$\mathrm{CaCl}_{2}, \mathrm{MgCl}_{2}, \mathrm{MgSO}_{4}$

$\mathrm{LiCl}$

$\mathrm{ZnCl}$,

$\mathrm{HgCl}_{2}$

Histidine

\begin{tabular}{|c|c|c|c|c|c|c|c|}
\hline \multicolumn{2}{|c|}{$\begin{array}{c}\text { Protease I } \\
(28000)\end{array}$} & \multicolumn{2}{|c|}{$\begin{array}{c}\text { Protease } 2 \\
(22500)\end{array}$} & \multicolumn{2}{|c|}{$\begin{array}{c}\text { Protease } 3 \\
(19500)\end{array}$} & \multirow{2}{*}{$\begin{array}{c}\text { Protease } 4 \\
(15500) \\
\mathrm{pH}\end{array}$} & \multirow{2}{*}{$\begin{array}{c}\text { Protease } 5 \\
(14500) \\
\mathrm{pH}\end{array}$} \\
\hline $\mathrm{pH}$ & $\mathrm{pH}$ & $\mathrm{pH}$ & $\mathrm{pH}$ & $\mathrm{pH}$ & $\mathrm{pH}$ & & \\
\hline $7 \cdot 6$ & $8 \cdot 8$ & $7 \cdot 6$ & $8 \cdot 8$ & $7 \cdot 6$ & 8.8 & $7 \cdot 6$ & $7 \cdot 6$ \\
\hline+ & + & + & + & + & + & + & + \\
\hline+ & + & - & - & - & - & + & + \\
\hline
\end{tabular}

RESULTS

Characterization of proteases by gelatin-PAGE

The number and approximate molecular weights of the extracellular proteases produced by $V$. alginolyticus cells in low-SNP medium in dishes containing the collagen matrices were determined by gelatin-PAGE at $\mathrm{pH} 7.6$ and 8.8 . Three major bands of protease activity with apparent molecular weights of approximately 28000,22500 and 19500 (proteases 1, 2 and 3, respectively) and two minor bands of protease activity with apparent molecular weights of approximately 15500 and 14500 (proteases 4 and 5, respectively) were obtained at $\mathrm{pH} 7 \cdot 6$ (Fig. 1). At $\mathrm{pH} 8.8$ the two minor bands of activity were absent and the activities of proteases 1,2 and 3 were decreased (Fig. 1). The production of the two minor proteases varied but they were always produced in small amounts and were often not detected after gelatin-PAGE at $\mathrm{pH} 7 \cdot 6$.

All quantitative comparisons were made on the same slab gel and experiments were repeated at least three times. Although variations did occur between runs with different gels the relative activities within each gel remained the same. The areas of the protease bands $1,2,3,4$ and 5 were $1 \cdot 2,2 \cdot 7,3 \cdot 4,0 \cdot 2$ and $0.04 \mathrm{~cm}^{2}$ respectively (Fig. 1).

\section{Effect of inhibitors}

The effect of various inhibitors (Table 1) on the activities of the proteases at $\mathrm{pH} 7.6$ and 8.8 was investigated after gelatin-PAGE by adding the inhibitors to the gelatin gels during 


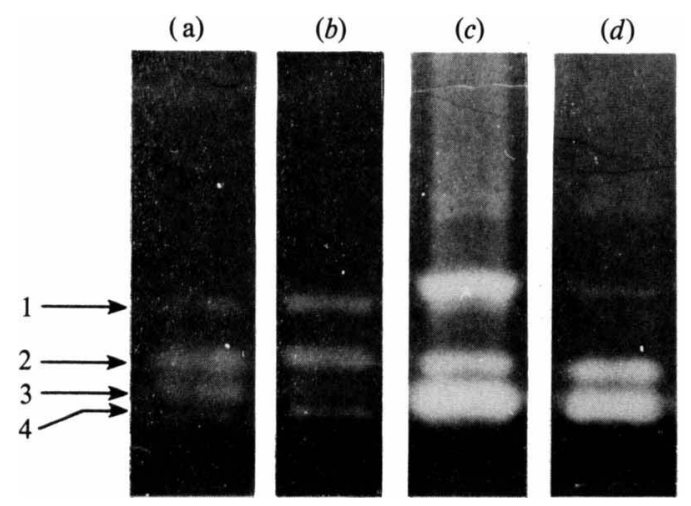

Fig. 2. Effect of histidine and temperature on the production of extracellular serine proteases by $V$. alginolyticus at $\mathrm{pH} 7 \cdot 6$. The lanes represent culture supernatants $(a)$ with, and $(b)$ without histidine $(0.5 \%)$; and culture supernatants at $(c) 30^{\circ} \mathrm{C}$, and $(d) 37^{\circ} \mathrm{C}$. The arrows indicate the positions of proteases 1, 2, 3 and 4 . Each lane was loaded with $1 \cdot 3 \mu \mathrm{g}$ protein.

incubation in $0 \cdot 1 \mathrm{M}$-glycine buffer at the appropriate $\mathrm{pH}$. All five proteases were inhibited at pH 7.6 and 8.8 by the serine protease inhibitors DFP and PMSF (Table 1), suggesting that they are all serine proteases. EDTA inhibited all the proteases but $o$-phenanthroline inhibited only proteases 1,4 and 5 (Table 1). The five proteases were not inhibited by sulphydryl reagents (PHMB and iodoacetamide) or by inhibitors of trypsin-like enzymes (TLCK, TPCK, benzamidine, soybean trypsin inhibitor, lima bean inhibitor, trasylol and ovomucoid). $\mathrm{HgCl}_{2}$ inhibited all five serine proteases whereas $\mathrm{CaCl}_{2}, \mathrm{MgCl}_{2}$ and $\mathrm{MgSo}_{4}$ had no effect. $\mathrm{LiCl}$ inhibited proteases 4 and $5 . \mathrm{ZnCl}_{2}$ inhibited proteases $1,3,4$ and 5 .

\section{Effect of histidine and temperature on the production of serine proteases}

The addition of histidine $(0.5 \%, \mathrm{w} / \mathrm{v})$ to the gelatin gels before incubation in $0.1 \mathrm{M}$-glycine buffer did not affect the activities of the five serine proteases (Table 1). However, the addition of histidine to the low-SNP medium during the growth of the cells in the culture dishes caused increased production of protease 1 , did not affect production of protease 2 and inhibited production of protease 3 (Fig. 2). The areas of the protease bands 1,2 and 3 without histidine were $0 \cdot 6,2.5$ and $1.6 \mathrm{~cm}^{2}$, respectively. In the presence of histidine the areas of the protein bands 1,2 and 3 were $1 \cdot 5,2 \cdot 6$ and $0 \cdot 2 \mathrm{~cm}^{2}$, respectively. The effect of histidine on the production of the two minor proteases 4 and 5 was difficult to determine and variable results were obtained.

We recently reported that the production of alkaline exoprotease activity was specifically regulated by temperature and was depressed at $37^{\circ} \mathrm{C}$ (Hare et al., 1981). Gelatin-PAGE analysis of supernatants from stationary phase peptone cultures incubated at $30^{\circ} \mathrm{C}$ and $37^{\circ} \mathrm{C}$ indicated that the synthesis of protease 1 was markedly depressed at $37^{\circ} \mathrm{C}$ (Fig. 2). The production of protease 3 at $37^{\circ} \mathrm{C}$ was also depressed but to a lesser extent than protease 1 . Production of protease 2 was not affected by changes in temperature between $30^{\circ} \mathrm{C}$ and $37^{\circ} \mathrm{C}$. The areas of the protease bands 1,2 and 3 at $30^{\circ} \mathrm{C}$ were $13.9,3.3$ and $11 \cdot 1 \mathrm{~cm}^{2}$, respectively, and at $37^{\circ} \mathrm{C}$ they were $0.4,3.8$ and $7.5 \mathrm{~cm}^{2}$, respectively. The effect of temperature on the production of the minor proteases 4 and 5 could not be determined due to the small and variable amounts of these enzymes which were produced.

\section{Gelatin-PAGE of a concentrated collagenase preparation}

Gelatin-PAGE of a commercial (Boehringer) preparation of $V$. alginolyticus collagenase revealed six bands of activity at $\mathrm{pH} 8.8$ with apparent molecular weights of approximately $45000,38500,33500,31000,19000$ and 16000 (Fig. 3). Similar results were obtained at pH 7.6. The 19000 and 16000 molecular weight bands were serine proteases as they were inhibited by DFP and PMSF. The other four bands of activity were not affected by these inhibitors. The first four bands of activity were inhibited by histidine, EDTA, $o$-phenanthroline and $\mathrm{ZnCl}_{2}$. 


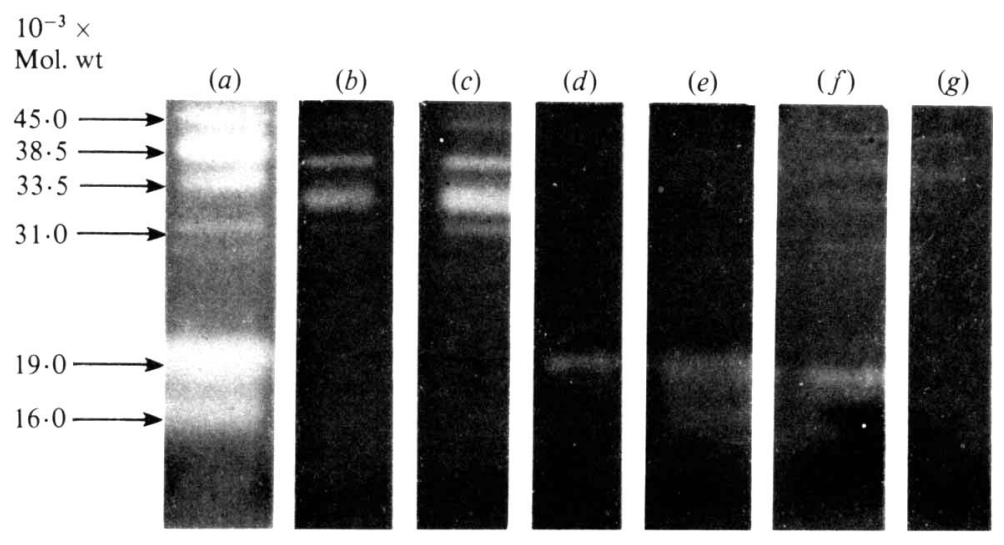

Fig. 3. Gelatin-PAGE of a commercial (Boehringer) $V$. alginolyticus collagenase preparation at $\mathrm{pH}$ 8.8. (a) Control collagenase preparation; $(b-g)$ collagenase preparation treated with: $(b)$ DFP $(10$ $\mathrm{mM}) ;(c)$ PMSF (10 mM); (d) histidine $(0.5 \%) ;(e) o$-phenanthroline $(1 \mathrm{mM}) ;(f) \mathrm{ZnCl}_{2}(1 \mathrm{mM}) ;$ and $(\mathrm{g})$ EDTA $(10 \mathrm{~mm})$. Each lane was loaded with $1 \cdot 3 \mu \mathrm{g}$ protein.

\section{Radioactive collagen matrix assay}

The suitability and specificity of the release of $\left[{ }^{3} \mathbf{H}\right]$ proline from the collagen matrices had been previously established for mammalian collagenases by Jones \& Scott-Burden (1979). We confirmed their findings and showed that the assay system was a sensitive assay procedure for bacterial collagenases. The addition of $5 \times 10^{8}, 5 \times 10^{9}$ and $5 \times 10^{10}$ cells ml ${ }^{-1}$ caused the release of 200,1100 and 2250 c.p.m. ml ${ }^{-1}\left[{ }^{3} \mathrm{H}\right]$ proline, respectively after $6 \mathrm{~h}$ incubation at $30^{\circ} \mathrm{C}$. Control uninoculated experiments showed no release of $\left[{ }^{3} \mathrm{H}\right]$ proline. $\mathrm{Cc}$ lagenase activity in the inoculated samples was not detected by the assay of Wünsch \& Heidrich (1963).

The addition of histidine $(0.5 \%)$ to the culture dishes resulted in a $75 \%$ decrease in the release of $\left[{ }^{3} \mathrm{H}\right]$ proline from the collagen matrices.

The release of $\left[{ }^{3} \mathrm{H}\right]$ proline from the collagen matrices by $V$. alginolyticus cells after $6 \mathrm{~h}$ incubation at $30^{\circ} \mathrm{C}$ was affected by aeration. Shaking the dishes on a rotary shaker at $0,70,100$ and 130 r.p.m. resulted in the release of $2000,4400,6500$ and 9100 c.p.m. ml ${ }^{-1}\left[{ }^{3} \mathrm{H}\right]$ proline, respectively. $\left[{ }^{3} \mathrm{H}\right]$ Proline was not released in control uninoculated dishes shaken at 130 r.p.m.

Although the production of collagenase by cells in the culture dishes could be detected by the release of $\left[{ }^{3} \mathrm{H}\right]$ proline from the collagen matrices, no collagenase bands (high molecular weight bands which were inactivated by histidine but were not inactivated by the serine protease inhibitors) were observed after gelatin-PAGE. The same samples contained the serine proteases 1, 2, 3, 4 and 5 which were detected by gelatin-PAGE. Total alkaline serine protease activity of these samples could also be measured by the azocasein assay method $\left(6.8\right.$ units $\mathrm{ml}^{-1}$ after $10 \mathrm{~h}$ incubation at $30^{\circ} \mathrm{C}$ ).

\section{Constitutive basal levels of collagenase}

The sensitive radioactive assay method was used to determine whether $V$. alginolyticus cells produced a constitutive basal level of extracellular collagenase and whether the cells could be pre-sensitized to produce collagenase. Low-SNP cultures which did not contain a collagenase inducer were resuspended and incubated for $6 \mathrm{~h}$ at $30^{\circ} \mathrm{C}$ in culture dishes with and without collagen matrices. The culture containing collagen matrices showed the release of $\left[{ }^{3} \mathrm{H}\right]$ proline (Fig. 4). After $6 \mathrm{~h}$ incubation the supernatants from the culture dishes with and without collagen matrices were added to fresh culture dishes containing collagen matrices. The release of $\left[{ }^{3} \mathrm{H}\right]$ proline by uninduced cell-free culture supernatants was more rapid than with induced cellfree culture supernatants (Fig. 4). The lower activity of the supernatants from dishes containing collagen matrices was presumably due to the affinity and binding of collagenase by the anchored substrate in the first culture dish. The washed cell suspensions from both the induced and uninduced cultures were added to fresh collagen matrices and exhibited similar levels of collagenase activity (Fig. 4). 


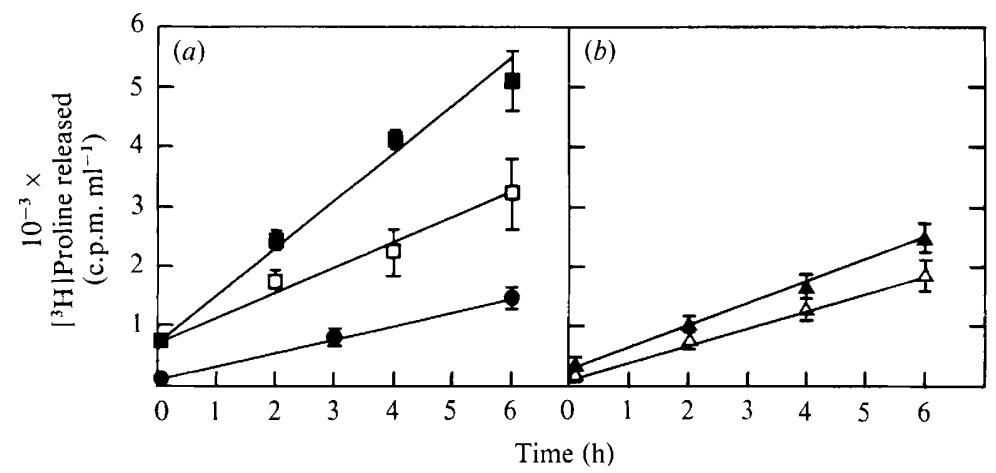

Fig. 4. Constitutive basal levels of collagenase produced by $V$. alginolyticus. (a) Collagenase activity of supernatant low-SNP culture solutions from $V$. alginolyticus cells pregrown in the presence ( $\square$ ) and absence ( $\square$ ) of collagen. Production of collagenase by cells added to a collagen matrix. The release of $\left[{ }^{3} \mathrm{H}\right]$ proline in the solution pregrown in the presence of collagen has been corrected for the amount of radioactivity carried over from the initial collagen matrix. (b) Production of collagenase by the washed cell suspensions from the $V$. alginolyticus cells pregrown in the presence $(\triangle)$ and absence $(\boldsymbol{\Delta})$ of collagen. The bars represent S.E.S.

\section{DISCUSSION}

Vibrio alginolyticus produces three major and two minor serine proteases. The minor proteases are produced in small amounts or have low activity and it is concluded that the serine protease activity is largely due to proteases 1,2 and 3 . These five proteases are not collagenases as they are inhibited by serine protease inhibitors which do not inhibit $V$. alginolyticus collagenase activity (Lecroisey et al., 1975). Studies on the effects of inhibitors and $\mathrm{pH}$ on activity, and of histidine and temperature on production, indicate that the three major serine proteases are different enzymes and not autodigestion fragments of one or two enzymes. The two minor proteases ( 4 and 5) have similar molecular weights and are inhibited by the same inhibitors.

Although the five serine proteases could be detected in culture supernatants by gelatinPAGE, no collagenase enzymes could be detected in the same supernatants by this technique. The supernatants possessed collagenase activity as they caused the specific release of $\left[{ }^{3} \mathrm{H}\right]$ proline from collagen matrices. Collagenase enzymes were only detected by gelatin-PAGE in concentrated and partially purified enzyme preparations from $V$. alginolyticus.

Previously we showed that serine protease production in $V$. alginolyticus cultures is stimulated by histidine (Long et al., 1981). This stimulation in the total serine protease activity is due to the production of a single serine protease (protease 1). The production of the other four proteases is either inhibited or unaffected by histidine. Histidine affects the production of enzymes since the serine protease enzyme activities of cell-free samples were not affected by histidine.

Studies on the effect of temperature indicate that the production of serine protease 1 is also specifically regulated by temperature and that this enzyme is responsible for the majority of the serine protease activity in $V$. alginolyticus cultures assayed by the azocasein method.

The four bands of collagenase activity in the commercial $V$. alginolyticus collagenase preparation are likely to be partial digests of the same enzyme. Undegraded $V$. alginolyticus collagenase has a molecular weight of 70000 (Keil-Dlouha \& Keil, 1978). Keil-Dlouha (1976) and Reid et al. (1980) reported that autodegradation of $V$. alginolyticus collagenase results in the production of at least three active fragments.

The release of $\left[{ }^{3} \mathrm{H}\right]$ proline from collagen matrices attached to culture dishes is a very sensitive and specific assay for bacterial collagenases. This assay is approximately 100 -fold more sensitive than the Wünsch \& Heidrich (1963) assay which uses a synthetic chromogenic substrate. The radioactive assay procedure indicated that uninduced $V$. alginolyticus cells produce a basal level of collagenase.

P.H. acknowledges a postgraduate research bursary from the South African Council for Scientific and Industrial Research. We thank Professor E. Dowdle and Miss C. Heussen (Department of Clinical Science, University of Cape Town) for assistance with the gelatin-PAGE and for supplying the protease inhibitors. 


\section{REFERENCES}

Hare, P., Long, S., Robb, F. T. \& Woods, D. R (1981). Regulation of exoprotease production by temperature and oxygen in Vibrio alginolyticus. Archires of Microbiology 130, 276-280.

Heussen, C. \& DowdLe, E. B. (1980). Electrophoretic analysis of plasminogen activators in polyacrylamide gels containing sodium dodecyl sulphate and copolymerized substrates. Analytical Biochemistry 102, 196-202.

Jones, P. A. \& Scott-Burden, T. (1979). Activated macrophages digest the extracellular matrix proteins produced by cultured cells. Biochemical and Biophysical Research Communications 86, 71-77.

KeIL-Dlouha, V. (1976). Chemical characterization and study of the autodigestion of pure collagenase from Achromobacter iophagus. Biochimica et biophysica acta 429, 239-25l.

KeIL-Dlouha, V. \& KeIL, B. (1978). Subunit structure of Achromobacter collagenase. Biochimica et biophysica acta 522, 218-228.

KeIL-Dlouha, V., Misrahi, R. \& KeIL, B. (1976). The induction of collagenase and a neutral proteinase by their high molecular weight substrates in Achromobacter iophagus. Journal of Molecular Biology 107, 293-305.

LeCroisey, A., KeIl-Dlouha, V., Woods, D. R., Perrin, D. \& KeIL, B. (1975). Purification, stability and inhibition of the collagenase from Achromobacter iophagus. FEBS Letters 59, $167-172$.

Long, S., Mothibeli, M. A., RobB, F. T. \& Woods, D. R. (1981). Regulation of extracellular alkaline protease activity by histidine in a collagenolytic Vibrio alginolyticus strain. Journal of General Microbiology 127, 193-199.

ReID, G. C., Robb, F. T. \& Woods, D. R. (1978). Regulation of extracellular collagenase production in Achromobacter iophagus. Journal of General Microbiology 109, 149-154.

Reid, G. C., Woods, D. R. \& Robb, F. T. (1980). Peptone induction and rifampicin insensitive collagenase production by Vibrio alginolyticus. Journal of Bacteriology 142, 447-454.

Robbertse, P. J., WoOds, D. R., REAy, A. M. \& RobB, F. T. (1978). Simple and sensitive procedure for screening collagenolytic bacteria and the isolation of collagenase mutants. Journal of General Microbiology. 106, 373-376.

WELTON, R. L. \& WoODS, D. R. (1973). Halotolerant collagenolytic activity of Achromobacter iophagus. Journal of General Microbiologv 75, 191-196.

WüNSCH, E. \& HEIDRICH, H. G. (1963). Zur quantitativen Bestimmung der Kollagenase. Hoppe-Seyler's Zeitschrift für physiologische Chemie 333, 149-151. 